\title{
Housing and Ethnicity in Soviet Tartu
}

HILL KULU, Senior Researcher

TIIT TAMMARU, Senior Researcher

Institute of Geography, University of Tartu, Estonia

\section{Abstract}

Research on residential and housing inequality in the cities under central planning has a long tradition. However, previous studies have mostly focused on age and social segregation, while ethnic differences have been poorly investigated. This research clarifies the ethnic differences in housing ownership and living conditions in Tartu, Estonia, in the Soviet period. We use individual-level data from the 1989 census and multivariate analysis. Our analysis shows that, first, non-Estonians had better access to state housing than Estonians. The ethnic differences decrease, but remain significant when controlling for compositional differences. Second, it appears that Estonians had more living space, while non-Estonians lived in more comfortable conditions. Differences in housing ownership and population composition explain most of the ethnic differences in housing size, but the differences in housing facilities remain. We argue that both the state policy and the different traditions and values were responsible for the housing differences between Estonians and non-Estonians in Tartu during the Soviet period. The role of the pre-WWII legacy should be considered as well.

Keywords: housing, ethnicity, multivariate analysis, Soviet Tartu

\section{Research on housing and residential differences in the socialist cities}

The official rhetoric of communist countries stressed egalitarian values; the reality was, however, different as studies on population segregation in the socialist cities indicate (Smith 1996, 77). These studies have focused on three characteristics of segregation - those of age, social status and ethnicity - and discuss the similarities and differences of segregation in countries under central planning compared to the Western countries. Respectively, the explanations focus on two broad sets of factors: the centralized allocation of housing specific to countries under central planning (Hegedüs 
and Tosics 1983; Ciechocinska 1987; Musil 1987) on the one hand, and attributes related to more universal human needs and resources on the other hand (Dangschat 1987; Rowland 1992; Kulu 2002a). The volume of research and agreement on the level and explanations of population segregation vary according to these three characteristics of age, social status and ethnicity.

First, there is widespread agreement that age was an important determinant of population segregation in the socialist cities; older parts of cities had typically an older population compared to the new housing developments (Lehmann and Ruble 1997, 1091; cf. Musil 1987, 32). The causes for such segregation were much rooted in the interplay between the population growth of cities, the building of new housing developments and the socialist system of centralized housing allocation (Rowland 1992); once living space was allocated to people it remained so for a long time, as it was difficult to acquire a new apartment or house (Ciechocinska 1987, 24; Sõjajärgse ... $2001,159)$. Second, the analyses of social segregation of population in socialist cities indicate a more diverse picture in regard to age. Earlier studies reveal a rather modest social segregation (e.g., Rukavishnikov 1978, 73-76), while later studies present significant differences of residence and housing according to education and occupation (e.g., Dangschat 1987, 55-57; Ladanyi 1989, 561; Rowland 1992, 586-587). This has also led to the more diverse explanations of social segregation compared to age-wise segregation. Some researchers argue that the centralized housing allocation system still had a very important equalizing effect in countries under central planning (Sillince 1985, 147; Ciechocinska 1987, 24), while others draw the conclusion that the socialist allocation system reinforced (rather than reduced) housing inequalities that sprang from more universal human capital attributes like education (cf. Szelenyi 1987, 7).

The third and most poorly studied aspect of population segregation in socialist cities is related to ethnicity (Ladanyi 1993, 31). This is surprising as the few studies in the field indicate that ethnic segregation was actually much deeper than social segregation (Rukavishnikov 1978; Ladanyi 1993, 38). Despite such evidence we are still lacking studies where ethnicity is the central concern. Furthermore, the explanations of ethnic segregation mostly refer to the ethnic differences in age and educational composition (Rowland 1992) or in employment structure and place of origin (Rukavishnikov 1978; Raitviir 1988) as the causes. The modest attention given to ethnic segregation under central planning is one motivator of our current research. The second motivator is related to the better availability of data and related new analytical opportunities. Previous studies have employed aggregate census data and have mostly used bivariate research methods. We have access to the individual-level census data and we use multivariate methods. These enable us to discriminate both the role of "compositional effect" and the factors related directly to ethnicity in housing inequality along the ethnic line. 
The aim of our paper is to outline the ethnic differences in housing ownership and living conditions and to clarify the causes of the differences under state socialism through the case study of Tartu, the second largest city of Estonia. We use individuallevel data from the 1989 census and multivariate methods. The article proceeds as follows. First, we will give an overview of the formation of the population and components of population change in Tartu since WW II. Then we will introduce the 1989 census data, the variables and methods. In analyzing the data we will focus on the ethnic differences in housing ownership and living conditions. This leads us finally to a discussion on the causes of ethnic segregation in countries under central planning.

\section{The population development of Tartu}

The settlement of Tartu was first mentioned in the written records in 1030, and it received town rights in 1230 as the first settlement in Estonia and third in the Baltic countries (Volkov 1980, 16; Tammaru 2001, 79). The town rose as a medieval war administration and trade center due to its advantageous location on the trade route between Europe and Russia (Rea 1960, 23). Soon Tartu joined the Hanseatic League and became the largest center in South Estonia and second largest in Estonia after Tallinn. However, Tartu lost its importance as a trade center in the mid-17th century when an alternative trade route between Europe and Russia was established (Tarvel and Piirimäe 1980,83), and the trade with the towns of the Hanseatic League ended (Palli 1998, 14). The main factor in the development of the town became the foundation of the university in 1632 by King Gustav Adolf of Sweden.

Two major functions - a university town, and the economic and service center of South Estonia with only modest industrial functions - characterized Tartu subsequent centuries including the first half of the 20th century. The start of the Soviet period after WW II brought with it the major industrialization drive in Estonia, which did not leave Tartu untouched. In addition to its previous main functions, its industrial function was strengthened and Tartu developed as a polyfunctional manufacturing center with machinery, textiles, food, building and the forest industry having the dominant role. The dramatic industrialization started rapid urbanization in Estonia, which is reflected also in the population dynamics of Tartu. There were 59,000 residents in Tartu in 1934 and 35,000 in 1945 (immediately after the war). In 1959, there were 73,000 people and in 1989, 113,000 (Figure 1). The population growth rates were at their peak just after WW II and decreased steadily thereafter (Figure 2). As such, the overall trend of population change in Tartu was similar to Estonia's urban population. The growth rates were only slightly lower compared to the total urban population, but higher compared to the total population of Estonia. The urban population of Estonia increased four-fold, the total population of the country almost doubled, and the population of Tartu more than tripled during the Soviet period. The lower-than-average population growth rates of Tartu compared to the total urban population could be the result of the semi-closed status of the town due to the location of a strategic military airport in the town. 
Figure 1. Population of Tartu, 1934-1989.

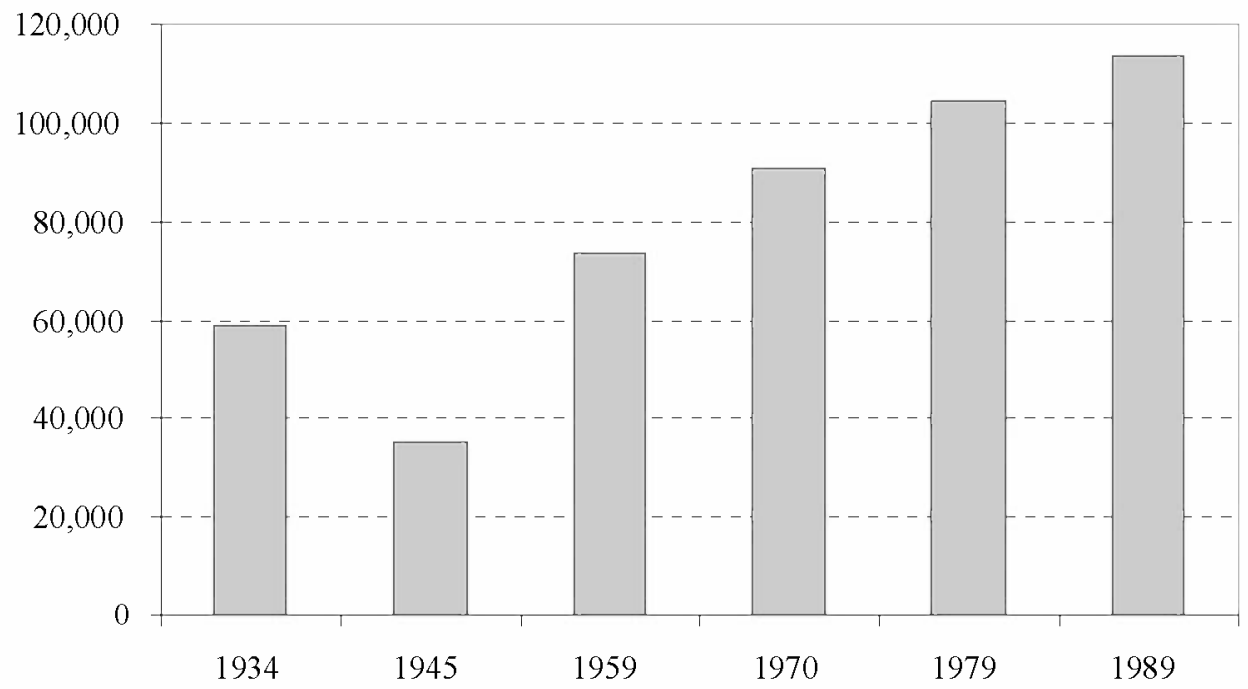

Figure 2. Mid-year population change (\%), 1945-1990.

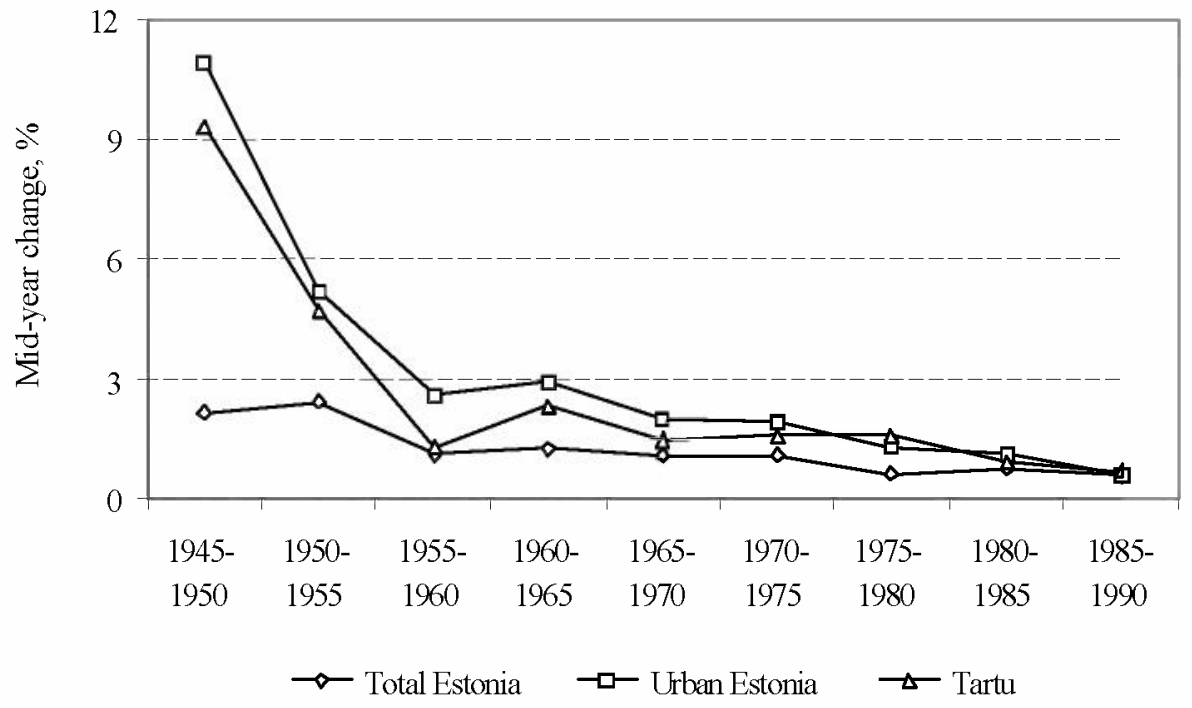


The population growth of Tartu was related both to positive net migration and positive natural increase throughout the Soviet period. Their relative importance, however, changed over time. Net migration dominated over natural increase just after WW II (Figure 3) due to the start up of massive industrialization and related very high in-migration as elsewhere in Estonia. Since then the share of migration started to decrease, and this decrease was much deeper in Tartu compared to both the urban and the total population in Estonia, although the overall downward trend was similar (cf. Tammaru 2002). The role of migration and natural increase in contributing to the total population change equalized in the mid-1960s in Tartu, and natural increase became the major source of population growth since the mid-1970s. The relative decrease of the role of migration in the population growth of Tartu was related to the quick decrease of net migration since the mid-1950s, as the natural population change was very stable throughout the Soviet period (excluding the 1940s), and higher than in Estonia's urban total and urban population since the 1970s. This means that natural increase dominated over net migration in the late Soviet Tartu.

Figure 3. Share of migration in total population change (\%), 1945-1990.

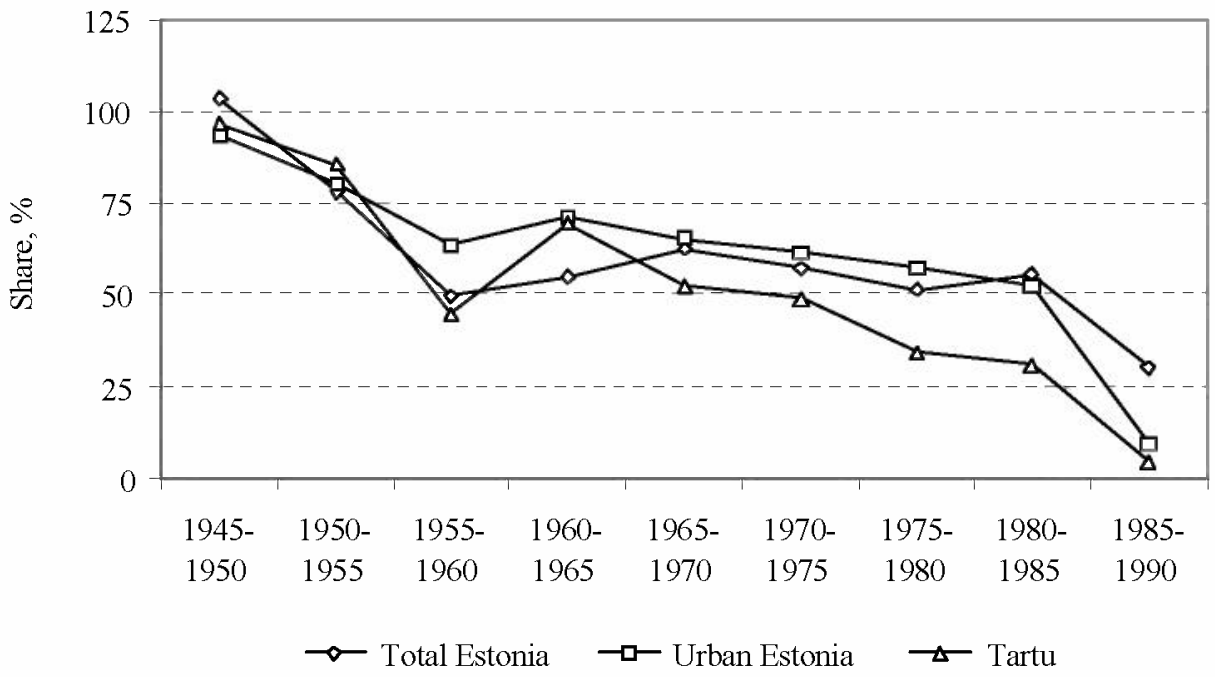

The high net migration just after WW II was due to both internal migration in Estonia, and immigration from the other parts of the Soviet Union, especially from Northwest Russia (Marksoo 1980, 251-252). Unfortunately, the role of both migration streams could only be evaluated indirectly by comparing overall population change with changes in the ethnic structure, and by using data on components of population growth. The share of Estonians in the total population of Tartu had continuously increased till WW II and composed about $97 \%$ by the start of the Soviet occupation (Figure 4). This means that only about 34,000 Estonians and 1,000 non-Estonians lived in Tartu in 
1945. The first post-WW II census was held in 1959 in the Soviet Union, which indicates that the number of Estonians increased by about 23,000 people and the number of non-Estonians by about 17,000 people in Tartu in 1945-1959. The net migration of about 35,000 people accounted for $\mathbf{8 8 \%}$ of the total population growth in 1945-1959. If it is assumed that the latter figure was similar for both Estonians and non-Estonians, and that Estonians participated mainly in internal migration and non-Estonians mostly in external migration, we can very roughly estimate that Tartu gained about 20,000 people through internal migration in Estonia, and about 15,000 people through immigration in 1945-1959. Thus, immigration accounted for $43 \%$ of the migration growth of Tartu in the immediate post-WW II decades, and the share of non-Estonians had increased to $24 \%$ by 1959 .

Figure 4. Share of Estonians in Tartu (\%), 1934-1989.

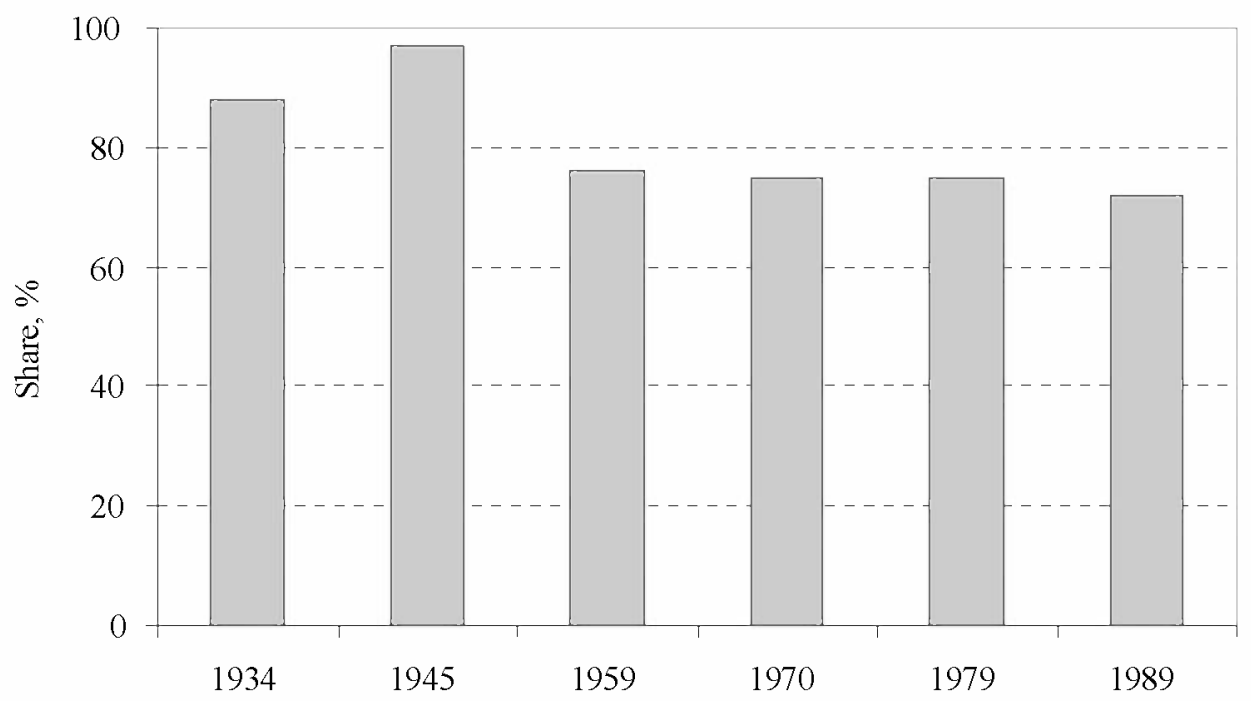

It is difficult to make comparable estimates of the role of internal migration and immigration in the population growth of post-1959 Tartu as migration accounted for only $47 \%$ of the population change in $1959-1990$. This leaves $53 \%$ to natural increase, whose ethnic distribution is unknown to us. Also, the internal migration of non-Estonians within Estonia increased as well since 1959 (Marksoo 1996, 5). However, what we do know is that the number of non-Estonians increased by 13,500 people in 19591989, which equals 44 percent of the total growth of non-Estonians in 1945-1989. The respective figures for Estonians were 48,500 people and 53\%. As natural increase was very likely higher among non-Estonians due to their younger age structure, and internal migration within Estonia contributed slightly to the growth of nonEstonians in Tartu as well, one could argue that the role of immigration was smaller in 
the total net migration of Tartu in 1959-1989 compared to the 1945-1959 period, which is similar to the urban population in general (cf. Tammaru 2002). This argument could be strengthened by the fact that the ethnic structure remained rather stable in Tartu since 1959 after the quick increase in the share of non-Estonians in 19451959 (Figure 4).

All in all, the number of non-Estonians increased from about 1,000 inhabitants in 1945 to 31,500 inhabitants in 1990 , accounting for $28 \%$ of the total population of Tartu. This figure was smaller in Tartu compared to Estonia's total $(38 \%)$ and urban (49\%) population. This means that Tartu gained less from post-WW II immigration as compared to both Estonia's total and urban population, as the share of non-Estonians was similar at the start of the Soviet period. Similarly to the rest of Estonia, Russians were the most numerous ethnic minority in Soviet Tartu ( $22 \%$ of the population), followed by Ukrainians, Ingrian Finns and Byelorussians, while the number of the pre-WW II second and third minority groups, the Germans and Swedes, was insignificant (Table 1).

Table 1. Population of Tartu by ethnic origin, 1989.

\begin{tabular}{lrc}
\hline & Number & Share, \% \\
\hline Estonians & 82,031 & 72.3 \\
Russians & 24,604 & 21.7 \\
Ukrainians & 2,639 & 2.3 \\
Finns & 1,275 & 1.1 \\
Byelorussians & 1,088 & 1.0 \\
Other & 1,783 & 1.6 \\
Total & 113,420 & 100.0 \\
\hline
\end{tabular}

Source: Census 1989.

The ethnic minority population was rather unequally distributed in the urban space of Soviet Tartu. Their share was high in the northeast of the city and also in some areas close to the center of the city, while relatively few non-Estonians lived elsewhere (Figure 5). Thus, we can clearly see the concentration of the ethnic minority population in certain areas of Tartu. Next, we will go further and will answer the question of whether housing ownership and living conditions also differed across ethnic lines in Soviet Tartu. 
Figure 5. Share of ethnic minorities in Tartu (\%), 1989.

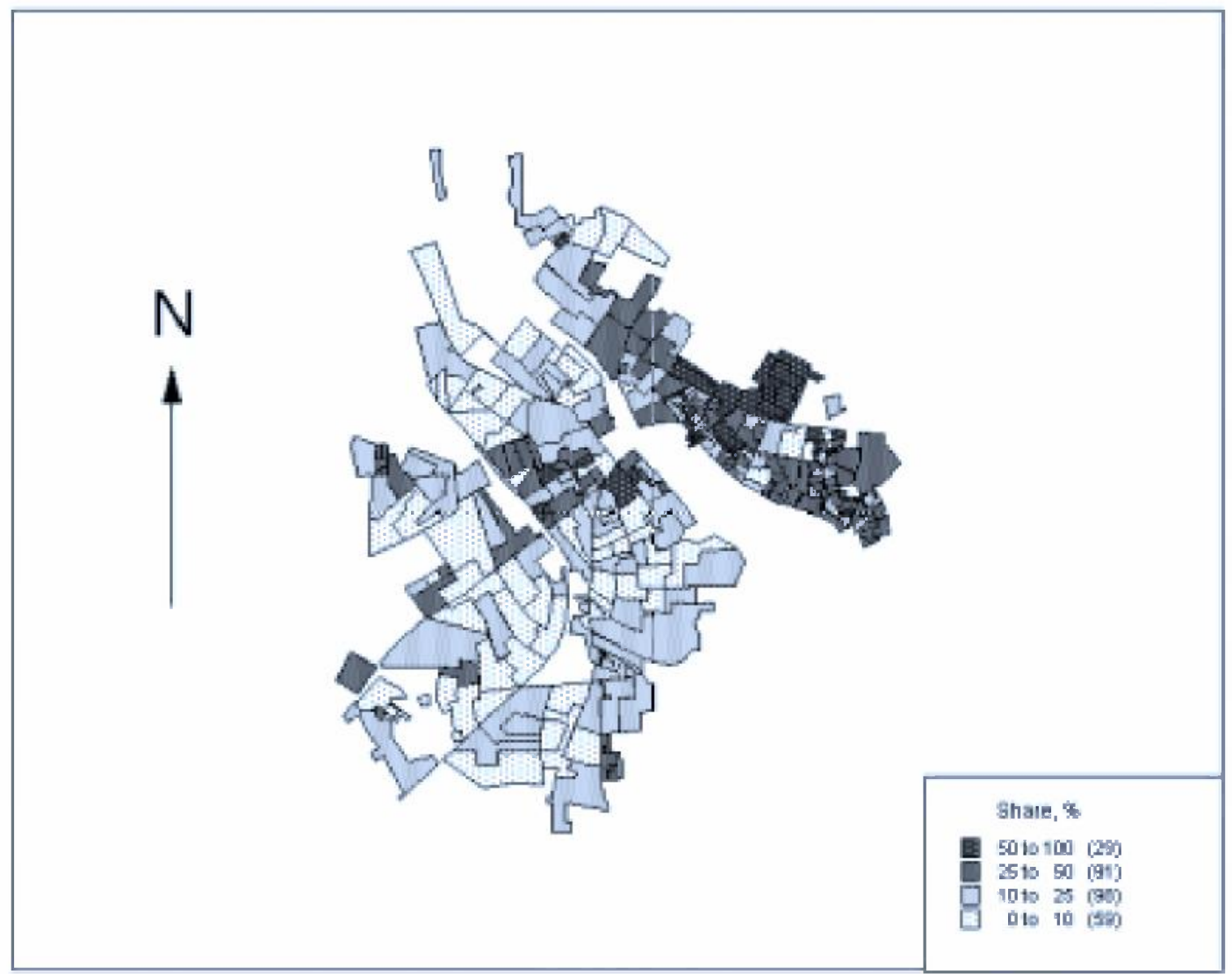




\section{Data and variables}

Our analysis of the ethnic differences in housing is based on the 1989 Soviet census data. The census collected information on both personal characteristics of people and their living conditions. Two types of questionnaires were used. The first contained twenty questions, thirteen of which focused on an individual's sociodemographic background. Seven of the questions requested information about an individual's living conditions. The second questionnaire, used for every fourth dwelling unit, had twentyfive questions containing additional questions on an individual's sociodemographic background. We use the data from a sample census of 28,632 permanent residents of Tartu. However, only people aged 15 and older who were owners or leaseholders have been included in the analysis. They form a total of 10,072 persons. Owners and leaseholders (instead of the total population) were selected for two reasons. First, their characteristics reflect the positions of households relative to the housing allocation process (Hegedüs and Tosics 1983, 467). Second, from the modelling point of view, including only one person from each household is a way to avoid possible biases in the parameter estimates and standard errors that results from the fact that the members of a household are not statistically independent (cf. Guo and Zhao 2000, 444).

In the analysis we use the dependent variables as follows. The first is "housing ownership" that is divided into the following categories: "private", "cooperative" and "state". "Private" includes all family houses, while "cooperative" and "state" cover apartments. Most of the apartments in Soviet Tartu were state-owned. However, since the late 1960 s, the state also built cooperative apartments that were partly paid for by the future residents themselves (cf. Kostinskiy 2001, 459). Because of inspection by the residents, the cooperative apartments were better constructed than the state-owned apartments. Second, we study the living conditions of the population. We analyze determinants of the size (square meters per capita) and the facilities of housing. For the latter we have composed a variable that has two values. The first value category covers housing that only has lower-order facilities: electricity and usually also cold water (and possibly sewerage). The second group of housing has higher-order facilities, in addition: hot water and (possibly) also a shower/bath and central heating.

The major explanatory variable of interest is an individual's ethnic origin. Estonians form $73 \%$ of our research population, non-Estonians (all other ethnic groups) comprise $27 \%$ (Table 2). The second variable is age as a control variable. We see that nonEstonians have a slightly younger age structure than Estonians. Next, we have an individual's education and employment sector as control variables. It appears that people with a higher level of education are somewhat over-represented among Estonians, while there are relatively more people with a secondary education among nonEstonians. We also see that Estonians are more often inactive or employed in education, while relatively many non-Estonians work in industry and public administration. 
We have also included an individual's place of origin in the analysis. There are more people born in Tartu among the Estonians, while migrants, especially of urban origin form an overwhelming majority among non-Estonians. Finally, the gender ratio is more equal among owners and leaseholders of Estonian origin. There are also more single people among the Estonians.

Table 2. Definitions and means of variables.

\begin{tabular}{|c|c|c|c|}
\hline Variable & Total & Estonians & Non-Estonians \\
\hline \multicolumn{4}{|l|}{ Ethnic origin } \\
\hline Estonian & 0.73 & & \\
\hline Non-Estonian & 0.27 & & \\
\hline \multicolumn{4}{|l|}{ Age } \\
\hline $15-24$ & 0.09 & 0.10 & 0.07 \\
\hline $25-34$ & 0.16 & 0.13 & 0.22 \\
\hline $35-49$ & 0.28 & 0.27 & 0.29 \\
\hline $50-59$ & 0.19 & 0.20 & 0.19 \\
\hline $60-74$ & 0.20 & 0.21 & 0.19 \\
\hline $75+$ & 0.08 & 0.09 & 0.04 \\
\hline \multicolumn{4}{|l|}{ Education } \\
\hline Higher & 0.22 & 0.24 & 0.19 \\
\hline Secondary & 0.44 & 0.42 & 0.49 \\
\hline Primary, basic & 0.34 & 0.35 & 0.32 \\
\hline \multicolumn{4}{|l|}{ Occupational sector } \\
\hline Industry & 0.22 & 0.20 & 0.27 \\
\hline Construction & 0.09 & 0.08 & 0.10 \\
\hline Other productive & 0.13 & 0.14 & 0.11 \\
\hline Health & 0.05 & 0.06 & 0.03 \\
\hline Education & 0.12 & 0.14 & 0.07 \\
\hline Public administration & 0.06 & 0.02 & 0.14 \\
\hline Other nonproductive & 0.04 & 0.04 & 0.04 \\
\hline Not indicated & 0.01 & 0.01 & 0.01 \\
\hline Inactive & 0.29 & 0.30 & 0.25 \\
\hline \multicolumn{4}{|l|}{ Place of origin } \\
\hline Native & 0.26 & 0.30 & 0.13 \\
\hline Urban, arrived $0-9$ years ago & 0.11 & 0.09 & 0.16 \\
\hline Urban, arrived $10+$ years ago & 0.22 & 0.18 & 0.33 \\
\hline Rural, arrived $0-9$ years ago & 0.07 & 0.07 & 0.07 \\
\hline Rural, arrived $10+$ years ago & 0.35 & 0.36 & 0.32 \\
\hline \multicolumn{4}{|l|}{ Gender } \\
\hline Male & 0.53 & 0.50 & 0.59 \\
\hline Female & 0.47 & 0.50 & 0.41 \\
\hline \multicolumn{4}{|l|}{ Family status } \\
\hline Married & 0.57 & 0.54 & 0.66 \\
\hline Not married & 0.43 & 0.46 & 0.34 \\
\hline $\mathbf{N}$ & 10,072 & 7,337 & 2,735 \\
\hline
\end{tabular}




\section{Methods}

In the data analyses, we will first describe the ethnic differences in housing ownership and living conditions in Soviet Tartu. Then we will clarify the ethnic differences in the probability to live in a state or cooperative apartment as compared to a private house, when the impact of other variables has been controlled. We will use a multinomial logistic regression model $($ Liao 1994,49$)$ that can be formalized as follows:

$$
\log \frac{p\left(Y_{i}=j\right)}{p\left(Y_{i}=J\right)}=\alpha+\sum_{k=1}^{K} \beta_{j k} X_{i k}
$$

Where $p\left(Y_{i}=j\right)$ is an individual's $i=1, \ldots I$ probability to live in a state $(j=1)$ or cooperative apartment $(j=2)$, and $p\left(Y_{i}=J\right)$ is the probability to live in a private house $(J=3)$. $\alpha$ is constant, $X_{z k}$ is the value of the variable for an indi-vidual and $\beta_{j k}$ is the parameter describing (on the log-odds scale) the impact of this variable, with $K$ variables.

Third, we will study the ethnic differences in the size and facilities of housing. Housing ownership as a control variable is also included in our models. A linear regression model will be used to study the determinants of housing size, and the model can be formalized as follows:

$$
Y_{i}=\alpha+\sum_{k=1}^{K} \beta_{k} X_{i k}
$$

Where $Y_{i}$ is the size (square meters per capita) of living space occupied by an individual's $i=1, \ldots$ I household.

To study the ethnic differences in housing facilities, we will use a binary logistic regression model that can be formalized as follows:

$$
\log \frac{p\left(Y_{i}=1\right)}{1-p\left(Y_{i}=1\right)}=\alpha+\sum_{k=1}^{K} \beta_{k} X_{i k}
$$

Where $p\left(Y_{i}=1\right)$ is an individual's $i=1, \ldots I$ probability to live in housing that has both lower- and higher-order facilities. 


\section{Ethnic differences in housing ownership and living conditions}

Seventy-six percent of the population of Tartu lived in state-owned housing in 1989 , $7 \%$ lived in cooperative housing and $16 \%$ in private housing (Table 3 ). However, significant ethnic differences did exist. While 71\% of Estonians lived in state housing, $91 \%$ of non-Estonians did so. Corresponding figures for private housing, in turn, were $21 \%$ and $3 \%$. Thus we can clearly see over-representation of non-Estonians in the state-owned dwellings. The data on living conditions are also revealing. Estonians had 15,2 $\mathrm{m} 2$ living space per capita and $55 \%$ of them lived in housing that had both lower- and higher-order facilities (Table 4). Corresponding figures for non-Estonians were $12,5 \mathrm{~m} 2$ and $70 \%$. Thus, Estonians had more space, while non-Estonians lived in more comfortable conditions. However, the situation differed in regard to housing ownership. Estonians had more space in cooperative and also in state apartments, while ethnic differences were insignificant in the case of those living in private housing. Non-Estonians, in turn, had more facilities in state housing, but those few living in private housing lived in less comfortable conditions than Estonians.

Table 3. Housing ownership by ethnic origin.

\begin{tabular}{lrcc}
\hline & Total & Estonians & Non-Estonians \\
\hline State housing & 76.4 & 71.0 & 91.1 \\
Cooperative housing & 7.1 & 7.6 & 5.7 \\
Private housing & 16.5 & 21.4 & 3.2 \\
Total & 100.0 & 100.0 & 100.0 \\
$\mathrm{~N}$ & 10,072 & 7,337 & 2,735 \\
\hline
\end{tabular}

Source: Census 1989. 
Table 4. Housing size ${ }^{1}$ and facilities ${ }^{2}$ by ethnic origin.

\begin{tabular}{|c|c|c|c|}
\hline & Total & Estonians & Non-Estonians \\
\hline \multicolumn{4}{|l|}{ Total } \\
\hline Size & 14.5 & 15.2 & 12.5 \\
\hline Facilities & 59.3 & 55.2 & 70.3 \\
\hline $\mathrm{N}$ & 10,072 & 7,337 & 2,735 \\
\hline \multicolumn{4}{|c|}{ State housing } \\
\hline Size & 12.9 & 13.3 & 12.2 \\
\hline Facilities & 64.1 & 61.0 & 70.7 \\
\hline $\mathrm{N}$ & 7,698 & 5,208 & 2,490 \\
\hline \multicolumn{4}{|c|}{ Cooperative housing } \\
\hline Size & 16.4 & 17.0 & 14.2 \\
\hline Facilities & 98.9 & 98.7 & 99.4 \\
\hline $\mathrm{N}$ & 716 & 559 & 157 \\
\hline \multicolumn{4}{|c|}{ Private housing } \\
\hline Size & 20.9 & 21.0 & 20.6 \\
\hline Facilities & 19.6 & 20.2 & 9.1 \\
\hline $\mathrm{N}$ & 1,658 & 1,570 & 88 \\
\hline
\end{tabular}

\section{Housing ownership}

Next, we specify the impact of ethnic origin on housing ownership. Only ethnic origin has been included in the first model (Table 5). The results show that non-Estonians were more likely to live in state housing than Estonians. Relative to private housing, their share was also larger in cooperative housing. Our second model also contains other personal variables. We see that the ethnic differences remain after controlling the impact of other personal variables. As the effect of some variables might differ across the ethnic line, we also tested major two-way interactions between ethnicity and other variables. One of the interactions proved to be significant and is presented in the third model. It appears that the impact of place of origin differed across ethnic origin. Earlier non-Estonian arrivals from rural areas were over-represented in state and cooperative housing, while new arrivals were under-represented. Estonians from rural areas were more equally distributed across the different housing sectors. 
Table 5. Multinominal logistic regression of housing ownership on characteristics of the population.

\begin{tabular}{|c|c|c|c|c|c|c|}
\hline Variable & $\begin{array}{l}\text { Model } 1 \\
\beta_{1}\end{array}$ & $\begin{array}{c}\text { Model } 2 \\
\beta_{1}\end{array}$ & $\begin{array}{c}\text { Model } 3 \\
\beta_{1}\end{array}$ & $\begin{array}{l}\text { Model } 1 \\
\beta_{2}\end{array}$ & $\begin{array}{c}\text { Model } 2 \\
\beta_{2}\end{array}$ & $\begin{array}{c}\text { Model } 3 \\
\beta_{2}\end{array}$ \\
\hline \multicolumn{7}{|c|}{ Ethnic origin (base: Estonian) } \\
\hline Non-Estonian & $2.144^{* * *}$ & $1.983^{* * *}$ & $2.085^{* * *}$ & $1.612^{* * *}$ & $1.673^{* * *}$ & $1.579 * * *$ \\
\hline \multicolumn{7}{|l|}{ Age (base: $35-49$ ) } \\
\hline $15-24$ & & $0.316^{* *}$ & $0.283^{*}$ & & -0.320 & -0.361 \\
\hline $25-34$ & & -0.089 & -0.083 & & 0.113 & 0.095 \\
\hline $50-59$ & & $-0.234 * * *$ & $-0.239 * * *$ & & -0.166 & -0.152 \\
\hline $60-74$ & & $-0.795^{* * *}$ & $-0.795 * * *$ & & $-0.705^{* * *}$ & $-0.693^{* * *}$ \\
\hline $75+$ & & $-0.943 * * *$ & $-0.938 * * *$ & & $-0.869 * * *$ & $-0.873^{* * *}$ \\
\hline \multicolumn{7}{|c|}{ Education (base: secondary) } \\
\hline Higher & & -0.079 & -0.077 & & $0.385^{* * *}$ & $0.377^{* * *}$ \\
\hline Primary, basic & & -0.069 & -0.070 & & $-0.451^{* * *}$ & $-0.454 * * *$ \\
\hline \multicolumn{7}{|c|}{ Employment sector (base: industry) } \\
\hline Construction & & $0.701^{* * *}$ & $0.700^{* * *}$ & & $-0.550^{* *}$ & $-0.550^{* *}$ \\
\hline Other productive & & $-0.244 * *$ & $-0.246^{* *}$ & & 0.166 & 0.169 \\
\hline Health & & $-0.400^{* * *}$ & $-0.399 * * *$ & & 0.165 & 0.165 \\
\hline Education & & 0.084 & 0.084 & & $0.514^{* * * *}$ & $0.510^{* * * *}$ \\
\hline Public administra & & $0.614^{* * *}$ & $0.609^{* * *}$ & & -0.254 & -0.245 \\
\hline Other nonproduc & & -0.113 & -0.114 & & -0.270 & -0.270 \\
\hline Not indicated & & $-0.512 * *$ & $-0.514^{* *}$ & & 0.092 & 0.100 \\
\hline Inactive & & -0.142 & -0.149 & & $-0.445^{* * *}$ & $-0.436 * *$ \\
\hline \multicolumn{7}{|c|}{ Place of origin (base: rural $10+$ ) } \\
\hline Urban $0-9$ & & $0.922 * * *$ & $0.882 * * *$ & & -0.376 & -0.522 \\
\hline Urban $10+$ & & $0.707 * * *$ & $0.687 * * *$ & & $0.447^{* * *}$ & $0.457 * * *$ \\
\hline Rural $0-9$ & & -0.012 & 0.118 & & $-0.505^{* *}$ & -0.403 \\
\hline Native & & 0.036 & 0.062 & & 0.018 & -0.074 \\
\hline \multicolumn{7}{|c|}{ Gender (base: male) } \\
\hline Female & & $0.183^{* * *}$ & $0.184 * * *$ & & $0.647^{* *}$ & $0.643^{* * *}$ \\
\hline \multicolumn{7}{|c|}{ Family status (base: married) } \\
\hline Not married & & $0.361 * * *$ & $0.361 * * *$ & & 0.046 & 0.047 \\
\hline \multicolumn{7}{|l|}{ Interactions } \\
\hline Non-Estonian*U & $0-9$ & & 0.923 & & & 1.336 \\
\hline Non-Estonian*U & $10+$ & & 0.122 & & & 0.102 \\
\hline Non-Estonian*R & $0-9$ & & $-1.087^{* * * *}$ & & & -0.901 \\
\hline Non-Estonian*N & & & -0.320 & & & 0.393 \\
\hline - $2 \log$ likelihood & 6087.12 & 5228.84 & 5205.91 & 6087.12 & 5228.84 & 5205.91 \\
\hline Chi square & 647.78 & 1506.06 & 1528.99 & 647.78 & 1506.06 & 1528.99 \\
\hline Df & 2 & 44 & 52 & 2 & 44 & 52 \\
\hline $\mathrm{N}=10,072$ & & & & & & \\
\hline
\end{tabular}

Significance: $*=10 \%, * *=5 \%, * * *=1 \%$.

Source: Census 1989. 
We will also briefly present the results of other major variables, although more detailed results and discussion can be found elsewhere (Kulu 2002a). First, we see that younger people were more likely to live in state and also cooperative dwellings than older people, especially those who were retired. We think that this difference mostly reflects the impact of the era. The older generations started their independent life in the first post-WWII decades when the share of single family dwellings was substantial among new housing stock. The working and family life of younger generations, in turn, began later when industrialized state and cooperative housing construction prospered (cf. Kõre et al. 1996, 2138-2139). Second, level of education is a good differentiator of the residents of the cooperative dwellings. People with a higher level of education were more likely to live in the cooperative apartments. Third, people employed in construction and public administration were over-represented in state housing. Those employed in education, in turn, were over-represented in the cooperative apartments. The better access of builders and the administrative élite to state housing corresponds to expectations (Lehmann and Ruble 1997, 1090). The overrepresentation of teachers in cooperative housing is not surprising, either, as it reflects both the state policy and the willingness of employees in education to spend relatively more resources on housing. Finally, it appears that migrants from the cities were more likely to live in state apartments than native residents born in Tartu or arrivals from rural areas. Earlier migrants from the cities were also over-represented in the cooperative dwellings.

\section{Living conditions: housing size}

Next, we clarify the ethnic differences in living conditions, and we begin with housing size. The results of our first model show that Estonians had more living space per capita than non-Estonians in Soviet Tartu (Table 6). When controlling the impact of housing ownership (the second model), ethnic differences decrease substantially, but remain significant. However, when other personal variables are also included in the analysis (the third model), ethnic differences are insignificant. Thus, the original ethnic differences mostly came from the compositional differences between Estonians and non-Estonians. Our further investigation shows that the differences in family status (more married people among non-Estonians, see also Table 2) and to a lesser extent in place of origin and in the employment sector are responsible for ethnic differences in housing size. (We also tested possible significant interactions with ethnicity, but did not find any.)

Regarding the impact of other major variables, we see that, first, older people had significantly more living space than younger people. This supports the idea that people continued to live in the housing they received when they were young even after their children had left home and they had retired (Ciechocinska 1987, 24; Sõjajärgse 2001, 159). Both low rents and the low activity in the housing market, resulting from the housing shortage, were responsible for the relatively low mobility of people. 
Table 6. Linear regression of housing size ${ }^{1}$ on characteristics of the population.

\begin{tabular}{|c|c|c|c|}
\hline Variable & $\begin{array}{c}\text { Model } 1 \\
\boldsymbol{\beta}\end{array}$ & $\begin{array}{c}\text { Model } 2 \\
\boldsymbol{\beta}\end{array}$ & $\begin{array}{c}\text { Model } 3 \\
\boldsymbol{\beta}\end{array}$ \\
\hline \multicolumn{4}{|c|}{ Ethnic origin (base: Estonian) } \\
\hline Non-Estonian & $-0.165^{* * * *}$ & $-0.087 * * *$ & -0.014 \\
\hline \multicolumn{4}{|l|}{ Age (base: 35-49) } \\
\hline $15-24$ & & & $-0.333 * * *$ \\
\hline $25-34$ & & & $-0.196^{* * * *}$ \\
\hline $50-59$ & & & $0.194 * * *$ \\
\hline $60-74$ & & & $0.324 * * * *$ \\
\hline $75+$ & & & $0.260 * * *$ \\
\hline \multicolumn{4}{|c|}{ Education (base: secondary) } \\
\hline Higher & & & $0.083 * * *$ \\
\hline Primary, basic & & & $-0.092 * * *$ \\
\hline \multicolumn{4}{|c|}{ Employment sector (base: industry) } \\
\hline Construction & & & -0.015 \\
\hline Other productive & & & 0.003 \\
\hline Health & & & 0.023 \\
\hline Education & & & 0.017 \\
\hline Public administration & & & $-0.078 * * *$ \\
\hline Other nonproductive & & & $-0.062 * *$ \\
\hline Not indicated & & & $0.139 * * *$ \\
\hline Inactive & & & $-0.078 * * *$ \\
\hline \multicolumn{4}{|c|}{ Place of origin (base: rural 10+) } \\
\hline Urban 0-9 & & & $-0.137 * * *$ \\
\hline Urban $10+$ & & & $0.022 *$ \\
\hline Rural 0-9 & & & $-0.170^{* * * *}$ \\
\hline Native & & & $0.040 * * *$ \\
\hline \multicolumn{4}{|l|}{ Gender (base: male) } \\
\hline Female & & & $-0.032 * * *$ \\
\hline \multicolumn{4}{|c|}{ Family status (base: married) } \\
\hline Not married & & & $0.332 * * *$ \\
\hline \multicolumn{4}{|c|}{ Housing ownership (base: private) } \\
\hline State & & $-0.406 * * *$ & $-0.343 * * *$ \\
\hline Cooperative & & $-0.162 * * *$ & $-0.152^{* * * *}$ \\
\hline R square & 0.02 & 0.09 & 0.34 \\
\hline Df & 1 & 3 & 24 \\
\hline $\mathrm{N}=10,072$ & & & \\
\hline
\end{tabular}

Source: Census 1989. 
Second, it appears that people with a higher level of education had larger housing than people with a lower level of education, both in state and private dwellings. This demonstrates that educated people had access to better housing and were also able (and willing) to mobilize more resources for housing (Dangschat 1987; Szelenyi 1987). Third, people employed in public administration (and in other non-productive sectors) had less space than others. The results concerning public administration are surprising and we could not find any explanation for this, except that they may somehow be related to the internal heterogeneity in this employment category. Finally, we see that native residents had larger housing than migrants, and migrants who had lived in Tartu longer had more space than new arrivals.

\section{Living conditions: housing facilities}

Non-Estonians had better-equipped housing than Estonians (Table 7, the first model). While controlling the impact of housing ownership (the second model), the effect of ethnicity decreases, but remains significant. When including other personal variables in the analysis (the third model), the impact of ethnic origin decreases further, but still remains significant. Therefore, ethnic differences in housing facilities only partly result from compositional differences (in family status and place of origin). We also tested major two-way interactions and two of them proved to be significant (the fourth model). Our results show that non-Estonians in state apartments had more facilities than Estonians, but in the case of those living in private houses the situation was more complex. While ethnic differences were missing among native residents in private dwellings, non-Estonian migrants, especially those from rural areas, had even fewer facilities than arrivals of Estonian ethnic origin.

The impact of other variables is as follows. First, older people had fewer facilities than younger ones. They lived in older apartments and family houses, which support the argument of the low residential mobility of middle-aged and older people in the Soviet society, and therefore the critical role of the era in shaping an individual's living conditions during her/his life. Young people (age 25-34) also had fewer facilities. This also corresponds to expectations as it took a while for a young family to get a state apartment or to build a house (cf. Kõre et al. 1996, 2145). Second, people with a higher level of education had better-equipped housing. This once more supports their better access to newer housing and their better ability to mobilize resources. Third, people employed in industry and especially in construction had more facilities than all other employees. Thus, employees of the productive sector (manufacturing) received better-equipped (newer) housing from the state and were also able to improve their existing living conditions more than workers in other (service) sectors. Again, this supports their favorable position relative to housing. 
Table 7. Logistic regression of housing facilities on characteristics of the population.

\begin{tabular}{|c|c|c|c|c|}
\hline Variable & $\begin{array}{c}\text { Model } 1 \\
\beta\end{array}$ & $\begin{array}{c}\text { Model } 2 \\
\boldsymbol{\beta} \\
\end{array}$ & $\begin{array}{c}\text { Model } 3 \\
\boldsymbol{\beta} \\
\end{array}$ & $\begin{array}{c}\text { Model } 4 \\
\beta\end{array}$ \\
\hline \multicolumn{5}{|l|}{ Ethnic origin (base: Estonian) } \\
\hline Non-Estonian & $0.657 * * *$ & $0.392 * * *$ & $0.282 * * *$ & $-0.748 *$ \\
\hline \multicolumn{5}{|l|}{ Age (base: 35-49) } \\
\hline $15-24$ & & & -0.092 & -0.161 \\
\hline $25-34$ & & & $-0.479 * * *$ & $-0.480 * * *$ \\
\hline $50-59$ & & & $-0.167 * *$ & $-0.165^{* *}$ \\
\hline $60-74$ & & & $-0.602 * * *$ & $-0.594 * * *$ \\
\hline $75+$ & & & $-1.264 * * *$ & $-1.236 * * *$ \\
\hline \multicolumn{5}{|l|}{ Education (base: secondary) } \\
\hline Higher & & & $0.406 * * *$ & $0.417 * * *$ \\
\hline Primary, basic & & & $-0.305 * * *$ & $-0.307 * * *$ \\
\hline \multicolumn{5}{|c|}{ Employment sector (base: industry) } \\
\hline Construction & & & $0.570^{* * *}$ & $0.580 * * *$ \\
\hline Other productive & & & $-0.255^{* * *}$ & $-0.250 * * *$ \\
\hline Health & & & -0.145 & -0.134 \\
\hline Education & & & $-0.356 * * *$ & $-0.347 * * *$ \\
\hline Public administration & & & $-0.366^{* * *}$ & $-0.294 * *$ \\
\hline Other nonproductive & & & $-0.390^{* * *}$ & $-0.378 * * *$ \\
\hline Not indicated & & & $-1.571 * * *$ & $-1.067^{* * *}$ \\
\hline Inactive & & & 0.071 & 0.059 \\
\hline \multicolumn{5}{|l|}{ Place of origin (base: rural 10+) } \\
\hline Urban $0-9$ & & & 0.071 & $0.255 * *$ \\
\hline Urban $10+$ & & & 0.092 & 0.038 \\
\hline Rural 0-9 & & & -0.161 & 0.088 \\
\hline Native & & & $-0.189 * * *$ & $-0.183 * * *$ \\
\hline \multicolumn{5}{|l|}{ Gender (base: male) } \\
\hline Female & & & -0.013 & -0.011 \\
\hline \multicolumn{5}{|l|}{ Family status (base: married) } \\
\hline Not married & & & $-0.592 * * *$ & $-0.595 * * *$ \\
\hline \multicolumn{5}{|c|}{ Housing ownership (base: private) } \\
\hline State & & $1.895 * * *$ & $1.874 \% * *$ & $1.810 * * *$ \\
\hline Cooperative & & $5.828 * * *$ & $5.911 * * *$ & $5.837 * * *$ \\
\hline \multicolumn{5}{|l|}{ Interactions } \\
\hline Non-Estonian*Urban 0-9 & & & & $-0.452 * * *$ \\
\hline Non-Estonian*Urban $10+$ & & & & 0.096 \\
\hline Non-Estonian*Rural 0-9 & & & & $-0.804 * * *$ \\
\hline Non-Estonian*Native & & & & 0.058 \\
\hline Non-Estonian*State & & & & $1.145^{* * *}$ \\
\hline Non-Estonian*Cooperative & & & & 1.292 \\
\hline -2 Log likelihood & 13418.17 & 11715.70 & 10937.87 & 10903.26 \\
\hline Chi square & 195.37 & 1897.84 & 2675.68 & 2710.28 \\
\hline $\mathrm{Df}$ & 1 & 3 & 24 & 30 \\
\hline $\mathrm{N}=10,072$ & & & & \\
\hline
\end{tabular}

Significance: $*=10 \%, * *=5 \%, * * *=1 \%$.

Source: Census 1989 


\section{Summary and discussion}

To sum up, our analyses then showed that, first, non-Estonians were more likely to live in state housing than Estonians. When controlling the impact of other personal variables, ethnic differences slightly decreased, but remained significant. Second, it appeared that Estonians had more living space, while non-Estonians lived in more comfortable conditions. Different housing ownership and population composition explained most of the ethnic differences in housing size, but the differences in housing facilities still remained. Next, we will discuss why ethnic groups had different access to housing in Soviet Tartu.

What then was the reason for the over-representation of non-Estonians in state housing? First, the role of the legacy of the pre-WWII period should certainly be mentioned. Some Estonians (both natives and migrants) had been living in Tartu already since pre-WWII, when single family dwellings formed a rather substantial part of the town's housing stock. Yet the majority of non-Estonians arrived (or were born) in the postwar city, when the construction of multi-family (state-owned) dwellings dominated. However, this is only a part of the explanation as the majority of people in Soviet Tartu, of both Estonian and non-Estonian origin, lived in housing built in the post-war period, including private houses (Kulu 2002a).

Second, we think that the different places of origin of Estonians and non-Estonians still had an effect. Migrants of non-Estonian origin came from other Soviet republics and cultural environments. They settled in Tartu when life's basic necessities were available there. Thus Tartu was the preferred destination when state-provided housing accompanied residential change. Migrants of Estonian origin, however, arrived mostly from areas close to Tartu and their settling in Tartu was less related to and dependent on receiving housing. Thus, non-Estonians arrived in Tartu from distant areas and through channels of "organized" migration (to use the well-known terminology of Rybakovskiy (1987), while most Estonians arrived in an "unorganized" manner from a short distance away. As organized migration was largely directed at certain economic sectors (industry, construction, public administration), the employment structure of Estonians and non-Estonians also began to diverge from each other, which, in turn, reinforced the ethnic differences in access to state housing. The concentration of non-Estonians in certain areas of Tartu (see Figure 5) further supported their arrival in the city through channels of organized migration.

Third, we still dare to argue that different traditions and values might also have a role in housing differences across the ethnic line. More specifically, the tradition of building a garden-town was rooted in the pre-WWII Estonian cities (Kotshenovski 1989; Tammaru 2001, 125-126), but did not spread in Russia. As a result, single family houses belonged to the urban mosaic in Estonia also during the Soviet period (Volkov 1989, 18-19; Kõre et al. 1996, 2145), while in Russia they were largely associated 
with rural areas (and small towns) or very poor living conditions on the fringes of the large cities (or suburban areas) (Kostinskiy 2001, 456). Thus, the different socialization environments of migrants of Estonian and Russian origins might have brought with them different desires and practices for housing in Tartu (cf. Kulu 2002b), which, in turn, shaped the desires and opportunities of their descendants born in the city.

Thus, on the one hand, our research shows that state policy played an important role in shaping the ethnic differences in housing in Soviet Tartu, although the differences between Estonians and non-Estonians were an unintended rather than an intended outcome of the policies. On the other hand, our results also point to the different traditions and values behind the housing differences in Tartu across the ethnic line. It is also evident that we need to continue our research efforts with an aim to better understand the factors behind the ethnic differences in housing in the cities under central planning. First, the ethnic differences in the Estonian cities with "various degrees" of socialism and in different periods should be compared using the 1959 to 1989 Soviet census data. Second, the role of in-migration to and residential mobility in the city in shaping the ethnic differences should be clarified. Third, the role of childhood socialization in an individual's later housing career should be studied. The data of the Estonian Family and Fertility Survey, with both information on residential and housing histories, should be a valuable source.

Acknowledgments: Funding for this research was provided by the Estonian Science Foundation (grant no. 4560) and the Estonian Ministry of Education (grant no. 0182143s02). The Estonian Interuniversity Population Research Centre provided us with the research data. We also thank the referee for valuable comments. 


\section{References}

Ciechocinska, M. 1987. Government interventions to balance housing supply and urban population growth: The case of Warsaw. International Journal of Urban and Regional Research 11:9-26.

Dangschat, J. 1987. Sociospatial disparities in a 'socialist' city: The case of Warsaw at the end of the 1970s. International Journal of Urban and Regional Research 11:37-59.

Guo, G. and H. Zhao. 2000. Multilevel modeling for binary data. Annual Review of Sociology $26: 441-462$.

Hegedüs, J. and I. Tosics. 1983. Housing classes and housing policy: Some changes in the Budapest housing market. International Journal of Urban and Regional Research 7:467495.

Kostinskiy, G. 2001. Post-socialist cities in flux. In: Handbook of Urban Studies, edited by R. Paddison, pp. 451-465. London: Sage.

Kotshenovski, O. 1989. Aedlinnalisus Eesti linnaehituslikus pärandis (Tähtvere linnaosa Tartus) [Garden-towns in the Estonian cities: Tähtvere district in Tartu]. Ehituse Teadusliku Uurimise Instituut, Ehitusalased uurimused, linnaehitus ja arhitektuur, pp. 5-19.

Kulu, H. 2002a. Housing differences in the late Soviet city: The case of Tartu, Estonia. Manuscript. Tartu: University of Tartu, Institute of Geography.

Kulu, H. 2002b. Socialization and residence: Ethnic return migrants in Estonia. Environment and Planning A 34:289-316.

Köre, J., M. Ainsaar and M. Hendrikson. 1996. Eluasemepoliitika Eestis 1918-1995 [Housing policy in Estonia in 1918-1995]. Akadeemia 8:2133-2164.

Ladanyi, J. 1989. Changing patterns of residential segregation in Budapest. International Journal of Urban and Regional Research 13:555-571.

Ladanyi, J. 1993. Patterns of residential segregation and the Gypsy minority in Budapest. International Journal of Urban and Regional Research 17:30-41.

Lehmann, S. G. and B. A. Ruble. 1997. From 'Soviet' to 'European' Yaroslavl: Changing neighbourhood structure in post-Soviet Russian cities. Urban Studies 34:1085-1107.

Liao, T. 1994. Interpreting Probability Models: Logit, Probit, and Other Generalized Linear Models. Quantitative Applications in the Social Sciences 101. London: Sage.

Marksoo, A. 1980. Elanikkond ja tervishoid [Population and health care]. In: Tartu Ajalugu, edited by R. Pullat, pp. 250-259. Tallinn: Eesti Raamat.

Marksoo, A. 1996. Role of external migration in urbanisation of Estonia. Paper presented at the 28th International Geographical Congress, The Hague, August 4-10.

Musil, J. 1987. Housing policy and the sociospatial structure of cities in a socialist country: The example of Prague. International Journal of Urban and Regional Research 11:27-36.

Palli, H. 1998. Eesti rahvastiku ajalugu aastani 1712 [The history of Estonia's population till 1712]. Tallinn: Teaduste Akadeemia Kirjastus.

Raitviir, T. 1988. Factorial ecological structure of Tallinn. In: Estonia: Geographical Researches, edited by J.-M. Punning, pp. 136-148. Tallinn: Estonian Geographical Society.

Rea, T. 1960. Eesti NSV linnaliste asulate geneetilisest klassifikatsioonist (sotsialismieelsel perioodil) [On the genetic classification of Estonia's towns before socialism]. Eesti Geograafia Seltsi Aastaraamat, pp. 18-39.

Rowland, R. H. 1992. Selected urban population characteristics of Moscow. Post-Soviet Geography 33:569-590.

Rukavishnikov, V. O. 1978. Ethnosocial aspects of population distribution in cities of Tataria. Soviet Sociology 3:59-79. 
Rybakovskiy, L. L. 1987. Migratsiya naseleniya: Prognozy, faktory, politika [Population migration: Projections, determinants, politics]. Nauka: Moskva.

Sillince, J. A. A. 1985. The housing market of the Budapest urban region, 1949-1983. Urban Studies 21:141-149.

Smith, D. 1996. The socialist city. In: Cities After Socialism: Urban and Regional Change and Conflict in Post-socialist Societies, edited by G. Andrusz, M. Harloe and I. Szelenyi, pp. 70-99. Oxford: Blackwell.

Sõjajärgse põlvkonna elutee ja seda kujundanud faktorid. 2001. [Life course of the postwar generation: Key influences]. Edited by M. Titma. Tartu: Tartu University Press.

Szelenyi, I. 1987. Housing inequalities and occupational segregation in state socialist cities: Commentary to the special issue of IJURR on east European cities. International Journal of Urban and Regional Research 11:1-8.

Tammaru, T. 2001. Linnastumine ja linnade kasv Eestis nõukogude aastatel [Urbanisation and urban growth in Estonia during the Soviet period]. Tartu: Tartu University Press.

Tammaru, T. 2002. Universal and specific features of urbanisation in Estonia under socialism: The empirical evidence of the sources of urban and rural population growth. The Professional Geographer 54:544-556.

Tarvel, E. and H. Piirimäe. 1980. Kaubandus. Käsitöö [Trade. Handcraft]. In: Tartu ajalugu, edited by R. Pullat, pp. 80-91. Tallinn: Eesti Raamat.

Volkov, L. 1980. Eestimaa asustus [The settlement of Estonia]. Tallinn: Eesti Raamat.

Volkov, L. 1989. Nõukogude Eesti arhitektuur [The architecture of Soviet Estonia]. Tallinn: Eesti NSV Ühing "Teadus". 